\title{
Pengaruh Sikap Mandiri, Lingkungan Keluarga, Motivasi, dan Pengetahuan Kewirausahaan Terhadap Minat Berwirausaha (Studi Pada Mahasiswa di Perguruan Tinggi Purwokerto)
}

\author{
Vyna Monicca Widiastuty ${ }^{(1)}$ \\ Program Studi Manajemen S1 \\ Fakultas Ekonomi dan Bisnis Universitas Muhammadiyah Purwokerto ${ }^{(1)}$ \\ Email : ${ }^{1}$ vynamonicca3232@gmail.com \\ Tri Septin Muji Rahayu ${ }^{(2)}$ \\ Program Studi Manajemen S1 \\ Fakultas Ekonomi dan Bisnis Universitas Muhammadiyah Purwokerto ${ }^{(2)}$ \\ Email : ${ }^{2}$ triseptinmujirahayu@ump.ac.id
}

\begin{abstract}
ABSTRAK
Penelitian ini bertujuan untuk menguji pengaruh sikap mandiri, lingkungan keluarga, motivasi, dan pengetahuan kewirausahaan terhadap minat berwirausaha. Populasi dalam penelitian ini adalah mahasiswa di perguruan tinggi Purwokerto. Pemilihan sampel dalam penelitian ini dilakukan dengan purposive sampling didapatkan 130 mahasiswa yang menjadi sampel dan data diperoleh dari respondendengan instrumen penelitian menggunakan kuesioner. Metode analisis menggunakan analisisregresi linier berganda. Hasil penelitian ini menunjukkan bahwa sikap mandiri berpengaruh positif dan signifikan, lingkungan keluarga berpengaruh positif dan signifikan, motivasi berpengaruh positif dan signifikan, dan pengetahuan kewirausahaan berpengaruh positif dan signifikan terhadap minat berwirausaha. Kata kunci : Sikap Mandiri, Lingkungan Keluarga, Motivasi, Pengetahuan Kewirausahaan, Minat Berwirausaha
\end{abstract}

\section{ABSTRACT}

This study aims to examine the effect of independent attitude, family environment, motivation, and entrepreneur knowledge towards interest of entrepreneurship. The populations in this study are University Students in Purwokerto. The selection of samples in this study was conducted by purposive sampling as many as 130 university students were used as samples. Data was obtained from respondents with research instruments by using a questionnaire. Based multiple linear regression analysis, the results of this study showed that independent attitude has positive and significant effects, family environment has positive and significant effects, motivation has positive and significant effects, and entrepreneur knowledge has positive and significant effects on entrepreneurship interests. Keyword : Independent Attitude, Family Environment, Motivation, Entrepreneur Knowledge, Interests Of Entrepreneurship

\section{PENDAHULUAN}

Wirausahawan telah menjadi perhatian penting dalam perkembangan perekonomian suatu negara. Wirausahawan adalah orang yang mengatur dan mengkoordinasikan faktor-faktor produksi. Mereka menggabungkan faktor produksi ini sehingga dapat menciptakan barang dan jasa.Menurut Hendro (2011) dalam Galih (2017) kewirausahaan adalah suatu kemampuan untuk mengelola sesuatu yang ada di dalam diri untuk ditingkatkan supaya lebih optimal sehingga dapat meningkatkan taraf hidup di masa mendatang. Dengan adanya kewirausahaan, maka dapat terciptanya lapangan pekerjaan yang lebih luas dan tidak bergantung kepada orang lain dalam mencari 
pekerjaan dan bisa membantu pemerintah untuk mengurangi pengangguran dengan cara membuka lapangan pekerjaan. Di Indonesia setiap tahunnya selalu ada pertambahan penduduk yang mana hal itu juga menimbulkan masalah baru. Masalah tersebut antara lain kurangnya lapangan pekerjaan yang tersedia, jumlah pekerjaan yang tersedia lebih sedikit dari jumlah para pencari kerja, Adapun mayoritas jumlah pencari kerja adalah lulusan sarjana yang mana setiap tahun jumlahnya selalu meningkat sedangkan pekerjaan yang tersedia semakin menipis yang berakibat pada pengangguran (www.bps.go.id).

Data terakhir yang diperoleh dari BPS, bulan Agustus 2020 menunjukan pengangguran lulusan perguruan tinggi presentasenya 7,35 persen. Salah satu cara untuk mengurangi pengangguran adalah dengan berwirausaha. Adapun jumlah wirausaha di Indonesia masih sangat kurang, menurut Menteri Perindustrian Republik IndonesiaAirlangga Hartanto, Indonesia membutuhkan setidaknya 4 juta wirusaha baru untuk turut mendorong penguatan stuktur ekonomi (https://kemenperin.go.id). Hermawan dan Sirine (2017) memaparkan bahwa minat berwirausaha adalah suatu perasaan yang ada di dalam diri seseorang untuk tertarik membuat atau menciptakan suatu usaha dan kemudian dapat mengorganisir, mengatur dan menanggung semua resiko atas usaha yang dijalaninya. Berdasarkan definisi tersebut dapat disimpulkan bahwa minat berwirausaha yaitu suatu kemampuan yang keluar dari rasa ketertarikan terhadap kegiatan berwirausaha untuk menciptakan suatu usaha yang bermanfaat untuk diri sendiri dan lingkungan sekitar hal itu guna memenuhi kebutuhan hidup, didasari dengan perasaan senang ketika menciptakan usaha baru dan tanpa rasa takut dengan resiko yang akan dihadapi, selalu mau belajar dari kegagalan yang dialami dan mau mengembangkan usaha yang di ciptakannya. Adapun untuk menumbuhkan minat berwirausaha terdapat beberapa faktor yang dapat menjadi pertimbangan untuk menumbuhkan minat berwirausaha diantaranya sikap mandiri, lingkungan keluarga, motivasi, dan pengetahuan kewirausahaan (Setiawan dalam Hutagalung, dkk 2017).

Menurut Irene dalam Anies, dkk (2016) menyatakan bahwa sikap mandiri yaitu suatu keinginan dan perilaku seseorang yang tidak mudah bergantung kepada orang lain untuk mengerjakan atau menyelesaikan tugas dan tanggung jawabnya. Dalam berwirausaha seseorang penting untuk memiliki sikap mandiri dimana dengan kemandirian seseorang dapat mengambil tindakan dalam mengambil keputusan dan bertanggung jawab atas keputusannya. Selain itu, kemandirian dapat menjadikan seseorang memiliki pendirian teguh pada dirinya dan tidak bergantung pada orang lain yang artinya dapat membuat orang tersebut mampu untuk memimpin usahanya atau dengan kata lain menjadi seorang wirausaha. Penelitian sikap mandiri yang dilakukan oleh Anies, dkk (2016) menunjukan bahwa sikap mandiri berpengaruh signifikan terhadap minat berwirausaha. Penelitian di dukung oleh Anies, dkk (2016) bertolak belakang dengan penelitian yang dilakukan Hermawan dan Sirine (2017) mereka mengungkapkan bahwa sikap mandiri tidak berpengaruh signifikan terhadap minat berwirausaha.

Menurut Semiawan, 2010 dalam Bongsu hutagalung, dkk (2017) Lingkungan keluarga adalah media pertama dan utama yang mempengaruhi perilaku anak. Lingkungan keluarga memiliki pengaruh terhadap minat berwirausaha karena semakin kondusif lingkungan keluarga disekitarnya maka akan semakin mendorong seseorang untuk menjadi wirausaha. Dalam keluarga akan ada interaksi sosial dimana seorang anak pertamakali belajar untuk memperhatikan keinginan orang lain, belajar untuk bekerja sama, belajar untuk saling membantu dan belajar berperan menjadi mahluk sosial yang memiliki norma dan ketrampilan tertentu dalam interaksi mereka dengan orang lain (Yusuf, 2012) dalam Hutagalung, dkk (2017). Penelitian lingkungan keluarga yang dilakukan oleh Anies, dkk (2016) menunjukan bahwa lingkungan keluarga berpengaruh 
signifikan terhadap minat berwirausaha. Penelitian di dukung oleh Anies, dkk (2016) bertolak belakang dengan penelitian yang dilakukan Pebi dan Agung A.K (2016) Mereka mengungkapkan bahwa lingkungan keluarga tidak berpengaruh signifikan terhadap minat berwirausaha.

Menurut Hadiprasetyo, 2014 dalam Putri dan Ramantha (2019) Motivasi adalah suatu usaha pendorong dalam rangka menumbuhkan keinginan sehingga dapat memberikan pengaruh dan dapat membuat seseorang melakukan kegiatan yang memiliki tujuan untuk mencapai suatu hal yang telah diinginkan. Motivasi bisa juga disebut suatu penggerak di dalam diri seseorang yang berhubungan dengan pemenuhan kebutuhan hidup sehinggal hal tersebut dapat mendorong seseorang untuk dapat menganalisis dan mengambil kesimpulan untuk mengambil tindakan guna mencapai tujuan. Penelitian motivasi yang dilakukan oleh Anies, dkk (2016) menunjukan bahwa motivasi berpengaruh signifikan terhadap minat berwirausaha. Penelitian di dukung oleh Anies, dkk (2016) bertolak belakang dengan penelitian yang dilakukan Hermawan dan Sirine (2017) mereka mengungkapkan bahwa motivasi tidak berpengaruh signifikan terhadap minat berwirausaha.

Menurut Mustofa, 2014 dalam Hermawan dan Sirine (2017) Pengetahuan kewirausahaan adalah suatu kemampuan individu dalam menghasilkan sesuatu hal yang baru dimana hal tersebut di dapat dari hasil pemikiran yang kreatif dan juga bertindak secara inovatif, sehingga dari hal tersebut dapat menghasilkan ide-ide atau peluang yang dapat dimanfaatkan dengan baik. Untuk mewujudkan sebuah kesuksesan seorang wirausahawan membutuhkan referensi sebagai rujukan dari sebuah sumber baik tercetak maupun elektronik. Kemudian dibutuhkan juga pengalaman yang dapat dipelajari ketika menjalankan usaha karena melalui pengalaman, seorang wirausahawan dapat mempelajari banyak hal. Penelitian Pengetahuan Kewirausahaan yang dilakukan oleh Hermawan dan Sirine (2017) mengungkapkan bahwa pengetahuan kewirausahaan berpengaruh positif signifikan terhadap minat berwirausaha. Namun hasil penelitian yang dilakukan Dini dan Agus (2018) mereka mengungkapkan bahwa motivasi tidak berpengaruh signifikan terhadap minat berwirausaha.Penelitian ini merupakan penelitian pengembangan dari penelitian Anies, Aleonardo dan Maria (2016) dengan hasil sikap mandiri, lingkungan keluarga dan motivasi berpengaruh signifikan terhadap minat berwirausaha. Dalam penelitian ini peneliti menambahkan variabel pengetahuan kewirausahaan dari penelitian Hermawan dan Sirine (2017) dengan hasil pengetahuan kewirausahaan berpengaruh signifikan terhadap minat berwirausaha. Subjek penelitian ini dilakukan pada mahasiswa perguruan tinggi di Purwokerto. Alasan peneliti memilih perguruan tinggi di Purwokerto sebagai tempat penelitian yaitu guna mengetahui pengaruh hubungan antara variabel yang diteliti dengan minat berwirausaha pada mahasiswa. Melihat dari latar belakang masalah diatas maka permasalahan dalam penelitian ini adalah apakah Sikap Mandiri, Lingkungan Keluarga, Motivasi dan Pengetahuan Kewirausahaan berpengaruh terhadap Minat Berwirausaha . Adapun tujuan penelitian ini adalah menganalisis pengaruh sikap mandiri, lingkungan keluarga, motivasi dan pengetahuan kewirausahaan terhadapa minat berwirausaha.

\section{TINJAUAN PUSTAKA}

\section{Sikap Mandiri}

Menurut Widayatun (2009) dalam Hermawan dan Siriene (2017) menjelaskan bahwa sikap merupakan keadaan mental, saraf serta kesiapan yang dapat diatur melalui sebuah pengalaman yang memberikan sebuah pengaruh dinamik ataupun terarah terhadap respon seseorang terhadap semua objek serta situasi yang berkaitan dengannya. Sedangkan Berdasarkan Theory of Planned Behavior (Azjen, 2005) menjelaskan 
mengenai perilaku yang dilakukan individu timbul karena adanya niat dari individu tersebut untuk berperilaku dan niat individu disebabkan oleh faktor internal dan eksternal dari individu tersebut. Sikap individu terhadap perilaku meliputi kepercayaan mengenai suatu perilaku, evaluasi terhadap hasil perilaku, norma subjektif, kepercayaan normatif dan motivasi untuk patuh. Menurut Irene dan Wardoyo (2012) dalam Hermawan dan Sirine (2017) bahwa sikap mandiri yaitu suatu keinginan dan perilaku seseorang yang tidak mudah tergantung pada orang lain untuk mengerjakan tugas dan tanggungjawabnya.

\section{Lingkungan Keluarga}

Menurut Semiawan, 2010 dalam Bongsu hutagalung, dkk (2017) Lingkungan keluarga adalah media pertama dan utama yang mempengaruhi perilaku anak. Orang tua juga bertindak sebagai pengarah untuk masa depan, artinya orang tua secara tidak langsung juga dapat mempengaruhi motivasi anak dalam memilih pekerjaan, termasuk dalam hal menjadi wirausahawan. Gunarsa dalam Roy Manihai (2009) dalam Anies, dkk (2016) bahwa lingkungan keluarga merupakan lingkungan pertama yang mula-mula memberikan pengaruh yang mendalam bagi anak.

\section{Motivasi}

Menurut Rusdiana, 2004 dalam Hermawan dan Sirine (2017) Motivasi dapat dipahami sebagai keadaan dalam diri individu yang menyebabkan mereka berperilaku dengan cara yang menjamin tercapainya suatu tujuan. Menurut Uno (2008) dalam Josia dan Hani (2017), Motivasi adalah dorongan dasar yang menggerakan seseorang bertingkah laku. Sarosa dalam Josia dan Hani (2017) juga berpendapat bahwa motivasi adalah suatu dorongan dari dalam diri seseorang yang mendorong orang tersebut untuk melakukan sesuatu, termasuk menjadi young entrepreneur. Indikator motivasi menurut Rusdiana (2004):

Motivasi material yaitu sebuah motivasi seseorang untuk mencapai hasil secara materiil (kekayaan).

Motivasi rasional-intelektual yaitu sebuah motivasi seseorang karena kepandaiannya untuk mengenali peluang usaha yang ada.

Motivasi emosional-sosial yaitu sebuah motivasi seseorang karena mampu menciptakan nilai tambah pada suatu produk.

\section{Pengetahuan Kewirausahaan}

MenurutMustofa (2014) dalam Josia dan Hani (2017) bahwa pengetahuan kewirausahaan adalah kemampuan seseorang untuk menghasilkan sesuatu yang baru melalui berpikir kreatif, dan bertindak inovatif, sehingga dapat menciptakan ide-ide atau peluang dan dapat dimanfaatkan dengan baik. Rusdiana (2014) dalam Josia dan Hani (2017) mengemukakan bahwa kewirausahaan merupakan kemauan dan kemampuan seseorang dalam menghadapi berbagai resiko dengan mengambil inisiatif untuk menciptakan dan melakukan hal-hal baru melalui pemanfaatan kombinasi berbagai sumber daya dengan tujuan untuk memberikan pelayanan yang terbaik kepada seluruh pemangku kepentingan dan memperoleh keuntungan sebagai konsekuensinya.

\section{Minat Berwirausaha}

Menurut Wijaya (2014) dalam Putu dan Agung (2016) berpendapat bahwa minat berwirausaha adalah kesediaan untuk bekerja keras disertai ketekunan guna mencapai kemajuan suatu usaha, begitupula bersedia untuk menanggung berbagai resiko yang berkaitan dengan tindakan yang dilakukan bersedia menempuh jalur serta cara yang baru dan bersedia belajar dari pengalaman. Minat berwirausaha menurut Subandono (2007) dalam Josia dan Hani (2017) adalah kecenderungan hati dalam diri subjek untuk tertarik 
menciptakan suatu usaha yang kemudian mengorganisir, mengatur, menanggung risiko dan mengembangkan usaha yang diciptakannya tersebut. Suryawan (2006) dalam Josia dan Hani (2017) mendefinisikan minat berwirausaha adalah keinginan, ketertarikan, serta kesediaan untuk bekerja keras atau berkemauan keras untuk berdikari atau berusaha memenuhi kebutuhan hidupnya tanpa merasa takut dengan resiko yang akan terjadi serta senantiasa belajar dari kegagalan yang dialami

\section{KERANGKA PEMIKIRAN DAN PENGEMBANGAN HIPOTESIS Pengaruh Sikap Mandiri $\left(\mathrm{X}_{1}\right)$ terhadap Minat Berwirausaha (Y)}

Sikap mandiri adalah suatu sikap atau perbuatan, perilaku atau mental yang membuat individu melakukan hal yang bermanfaat untuk dirinya tanpa harus menyusahkan orang lain. Salah satu faktor yang menjadi dorongan seseorang untuk berwirausaha adalah sikap mandiri, karena kemandirian merupakan salah satu ciri kualitas hidup manusia yang memiliki peran penting bagi kesuksesan hidup individu.

Dalam Penelitian Anies, Aleonardo dan Maria (2016) menyatakan bahwa Sikap Mandiri berpengaruh positif terhadap minat berwirausaha. Selanjutnya, dalam penelitian Grisna dan Wawan (2016) menyatakan bahwa Sikap Mandiri berpengaruh positif terhadap minat berwirausaha.

\section{Pengaruh Lingkungan Keluarga $\left(\mathbf{X}_{2}\right)$ terhadap Minat Berwirausaha (Y)}

Lingkungan keluarga adalah pendidikan utama yang diberikan dari keluarga inti kepada anak, pendidikan itu berisi tentang tuntunan atau contoh contoh yang dapat dijadikan anak untuk bisa hidup bermasyrakat.

Dalam penelitian Anies, Aleonardo dan Maria (2016) menyatakan bahwa Lingkungan Keluarga berpengaruh positif tethadap minat berwirausaha. Selanjutnya dalam penelitian Rifa'tul \& Bambang (2015) menyatakan bahwa Lingkungan Keluarga berpengaruh positif terhadap minat berwirausaha.

\section{Pengaruh Motivasi $\left(\mathbf{X}_{3}\right)$ terhadap Minat Berwirausaha $(\mathbf{Y})$}

Motivasi adalah suatu perasaan yang muncul di dalam diri individu, dari perasaan itu menjadi penggerak dalam diri individu untuk melakukan suatu hal atau tujuan yang akan dicapai. Motivasi juga dapat diartikan faktor yang sangat berpengaruh pada diri seseorang untuk menentukan apa yang menjadi keinginan dan usahanya untuk mewujudkan keinginannya tersebut.

Dalam penelitian Anies, Aleonardo dan Maria (2016) menyatakan bahwa Motivasi berpengaruh terhadap minat berwirausaha. Selanjutnya, dalam penelitian Syahid dan Masayu (2019) menyatakan bahwa Motivasi berpengaruh terhadap minat berwirausaha. Pada penelitian Josia dan Hani (2017) Motivasi tidak berpengaruh terhadap minat berwirausaha.

\section{Pengetahuan Kewirausahaan $\left(\mathbf{X}_{3}\right)$ dengan variabel Minat Berwirausaha ( $Y$ )}

Pengetahuan kewirausahaan adalah suatu kemampuan individu dalam menghasilkan sesuatu hal yang baru dimana hal tersebut di dapat dari hasil pemikiran yang kreatif dan juga bertindak secara inovatif, sehingga dari hal tersebut dapat menghasilkan ide-ide atau peluang yang dapat dimanfaatkan dengan baik.

Dalam penelitian Rifa'tul \& Bambang (2015) menyatakan bahwa Pengetahuan Kewirausahan berpengaruh positif terhadap minat berwirausaha. Selanjutnya dalam penelitian Josia \& Hani (2017) menyatakan bahwa Pengetahuan Kewirausahaan berpengaruh positif terhadap minat berwirausaha 


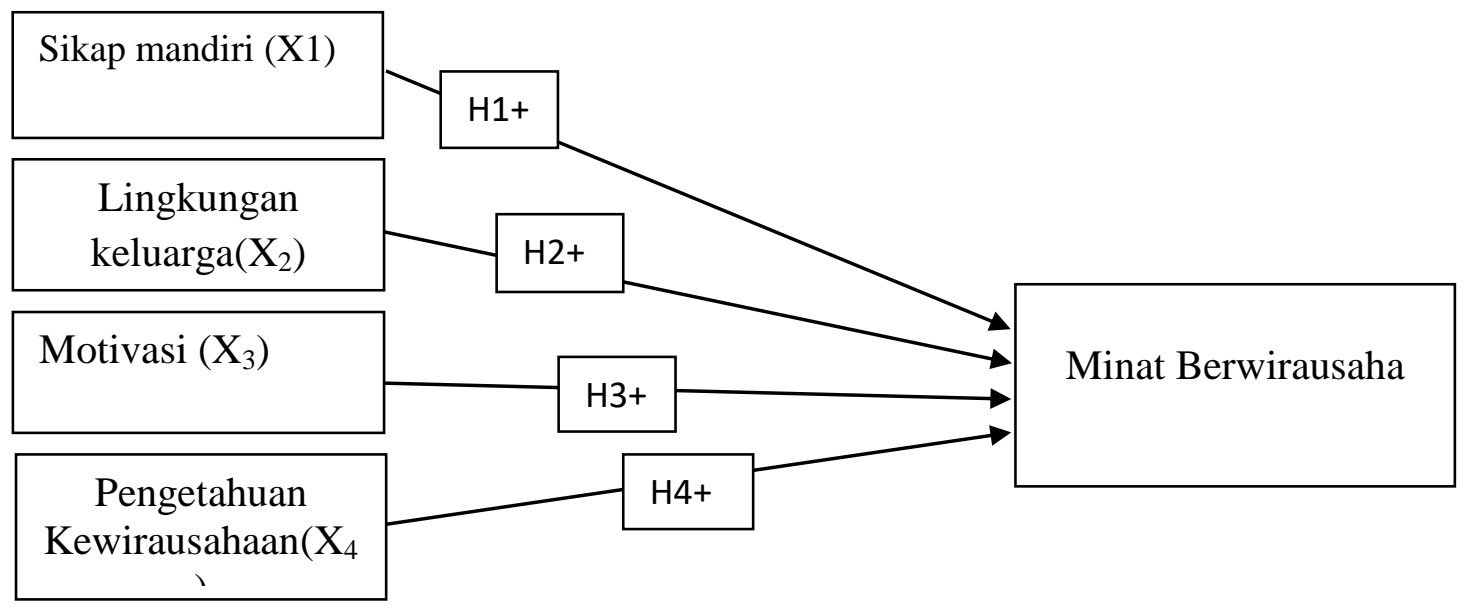

Gambar 2.1 Kerangka Pemikiran

\section{Hipotesis}

Hipotesis yang dapat dibuat adalah sebagai berikut

$\mathrm{H}_{1}$ : Sikap mandiri berpengaruhpositif dan signifikan terhadap minat berwirausaha mahasiswa perguruan tinggi di purwokerto.

$\mathrm{H}_{2}$ : Lingkungan keluarga berpengaruhpositif dan signifikan terhadap minat berwirausaha mahasiswa perguruan tinggi di purwokerto

$\mathrm{H}_{3}$ : Motivasi berpengaruh positif dan signifikan terhadap minat berwirausaha mahasiswa perguruan tinggi di purwokerto.

$\mathrm{H}_{4}$ : Pengetahuan kewirausahaan berpengaruhpositif dan signifikan terhadap minat berwirausaha mahasiswa perguruan tinggi di purwokerto.

\section{MetodePenelitian}

Metode penelitian ini menggunakan metode kuantitatif. Populasi adalah wilayah generelasi yang terdiri atas objek/wilayah yang mempunyai kuantitas dan karakteristik tertentu yang ditetapkan oleh peneliti untuk dipelajari dan kemudian ditarik kesimpulannya (Sugiyono 2015:148). Populasi penelitian ini adalah Mahasiswa di perguruan tinggi purwokerto. Lokasi penelitian ini bertempat di Purwokerto. Menurut Sugiyono (2016:149), Sampel adalah bagian dari jumlah dan karakteistik yang dimiliki oleh populasi tersebut. Dalam pemilihan sampel terdapat teknik untuk menentukan sampel mana yang akan digunakan dalam penelitian. Dalam penelitian ini subjek yang akan diteliti merupakan mahasiswa di 3 perguruan tinggi di Purwokerto yaitu Universitas Muhammadiyah Purwokerto, Universitas Jendral Soedirman dan Institut Agama Islam Negeri Purwokerto karena merupakan perguruan tinggi terbesar di purwokerto.

Adapun kriteria responden dalam penelitian ini adalah Mahasiswa Aktif di perguruan tinggi Universitas Jendral Soedirman, Universitas Muhammadiyah Purwokerto dan Institut Agama Islam Negri Purwokerto.Jumlah sampel dalam penelitian menjadi 130. Teknik analisis data yang digunakan dalam penelitian ini yaitu statistik deskriptif, uji validitas, uji relabilitas, uji asumsi klasik, analisis regresi linear berganda, uji kecocokan atau ketepatan model, dan uji hipotesis. 


\section{HASIL DAN PEMBAHASAN \\ Hasil Penelitian \\ Gambaran Data atau Sampel}

Responden dalam penelitian ini adalah mahasiswa aktif di perguruan tinggi yaitu Universitas Muhammadiyah Purwokerto, Universitas Jenderal Soedirman, dan Institut Agama Islam Negeri Purwoketo.Metode yang digunakan dengan teknik random sampling. Penyebaran kuesioner di lakukan offline dengan menggunakan hardfile kuesioner. Selama penyebaran kuesioner, jumlah kuesioner yang disebar kepada responden sebanyak 130 kuesioner dan kuesioner yang kembali sebanyak 130 kuesioner.

\section{Uji Asumsi Klasik \\ Uji normalitas}

Berdasarkan penelitian ini diketahui bahwa nilai Asymp.Sig(2 -tailed $)$ sebesar 0,897 dapat disimpulkan bahwa data unstandardized residual telah berdistribusi normal, karena nilai tersebut $>0,05$ sehingga dapat melanjutkan uji selanjutnya.

\section{Uji Multikolinearitas}

Berdasarkan penelitian ini menunjukan bahwa masing-masing variabel Sikap Mandiri memiliki nilai Tolerance 0,566>0,10. Pada variabel Lingkungan Keluarga memiliki nilai Tolerance 0,590>0,10, variabel Motivasi memiliki nilai Tolerance 0,768> 0,10, dan variabel PengetahuanKewirausahaan memiliki nilai Tolerance 0,764>0,10. Begitu juga dengan nilai VIF masing-masing variabel memiliki nilai $\leq 10$. Pada variabel Sikap Mandiri memiliki nilai VIF $1,767 \leq 10$, variabel Lingkungan Keluarga memiliki nilai 1,694 VIF $\leq 10$, variabel Motivasi memiliki nilai VIF $1,302 \leq 10$, dan variabel Pengetahuan Kewirausahaan memiliki nilai VIF 1,309 $\leq 10$. Dari data tersebut maka data penelitian ini bebas dari asumsi multikolinearitas.

\section{Uji Heteroskedastisitas}

BerdasarkanpenelitianinidapatdiketahuibahwanilaisignifikansidarivariabelSikap Mandiri $0,573 \geq 0,05$, variabelLingkunganKeluarga $0,517 \geq 0,05$, variabelMotivasi 0,164 $\geq 0,05$, dan variabelPengetahuan $0,442 \geq 0,05$ makadapatdisimpulkanbahwa data yang digunakan pada variabelSikapMandiri (X1), LingkunganKeluarga(X2), Motivasi (X3), dan Pengetahuan (X4) tidak terjadi gejala heterokedastisitas.

\section{Uji RegresiLinierBerganda}

Tabel 1 Analisis regresi liliner berganda

Coefficients $^{\mathrm{a}}$

\begin{tabular}{llrrrrr}
\hline \multirow{2}{*}{ Model } & \multicolumn{2}{c}{$\begin{array}{c}\text { Unstandardized } \\
\text { Coefficients }\end{array}$} & $\begin{array}{c}\text { Standardized } \\
\text { Coefficients }\end{array}$ & \multirow{2}{*}{ T } & \multirow{2}{*}{ Sig. } \\
\cline { 2 - 4 } & \multicolumn{1}{c}{ B } & \multicolumn{2}{c}{ Std. Error } & Beta & & \\
\hline & (Constant) &, 150 &, 290 & &, 519 &, 605 \\
& X1 &, 150 &, 072 &, 153 & 2,089 &, 039 \\
1 X2 &, 412 &, 069 &, 426 & 5,953 &, 000 \\
& X3 &, 081 &, 038 &, 133 & 2,115 &, 036 \\
X4 &, 310 &, 061 &, 318 & 5,052 &, 000 \\
\hline
\end{tabular}

a. Dependent Variable: Y 
Berdasarkan hasil analisis regresi tersebut diatas, dapat disusun persamaan regresi sebagai berikut :

$$
\begin{aligned}
& Y=\alpha+\beta_{1} X_{1}+\beta_{2} X_{2}+\beta_{3} X_{3}+\beta_{4} X_{4}+e \\
& Y=0,150+0,150 X 1+0,412 X 2+0,081 X 3+0,310 X 4
\end{aligned}
$$

Berdasarkan hasil uji regresi linier berganda ditemukan hasil variabel paling berpengaruh dalam penelitian ini yaitu variabel Lingkungan Keluarga (X2) dengan nilai Beta sebesar 0,412 .

\section{Uji Determinasi (R Square)}

Berdasarkan penelitian ini dapat dilihat bahwa nilai Adjusted $\mathrm{R}^{2}$ model regresi yang terbentuk dalam penelitian ini adalah sebesar 0,610 yang artinya sebesar 61,0\% variasi variabel Minat Berwirausaha dapat dijelaskan oleh variabel Sikap Mandiri, Lingkungan Keluarga, Motivasi dan Pengetahuan. Sedangkan sisanya sebesar 39,0\% dijelaskan oleh variabel lain yang tidak diteliti.

\section{PengujianHipotesis}

\begin{tabular}{|c|c|c|c|c|c|c|}
\hline \multicolumn{7}{|c|}{ ANOVA $^{a}$} \\
\hline \multicolumn{2}{|c|}{ Model } & Sum of & Df & Mean Square & $\mathrm{F}$ & Sig. \\
\hline \multirow{3}{*}{1} & Regression & 14,277 & 4 & 3,569 & 51,413 &, $000^{\mathrm{b}}$ \\
\hline & Residual & 8,678 & 125 & ,069 & & \\
\hline & Total & 22,955 & 129 & & & \\
\hline
\end{tabular}

Tabel 2. Uji Simultan (Uji f)

a. Dependent Variable: Y

b. Predictors: (Constant), X4, X3, X2, X1

Berdasarkan penelitian ini dapat diketahui nilai $\mathrm{F}$ hitung model pertama adalah 51,413 dengan nilai signifikansi 0,000 Sedangkan $F$ tabel pada tingkat signifikansi 0,05 adalah sebesar 2,44. Dengan demikian F hitung > F tabel $(51,413>2,44)$. Maka dapat disimpulkan bahwa uji hipotesis pertama yang menyatakan bahwa variabel Sikap Mandiri, Lingkungan Keluarga, Motivasi, dan Pengetahuan berpengaruh secara simultan terhadap Minat Berwirausaha diterima.

\section{Uji Parsial (Uji t)}

\section{Pengaruh Sikap Mandiri Terhadap Minat Berwirausaha}

Hasil pengujian hipotesis (H2) telah membuktikan bahwa variabel sikap mandiri berpengaruh positif dan signifikan terhadap minat berwirausaha dengan nilai $\mathrm{t}$ hitung $>\mathrm{t}$ tabel yaitu 2,089> 1,657 dengan nilai signifikansi sebesar $0,039<0,05$, yang artinya mahasiswa memiliki sikap mandiri di dalam dirinya yang menjadikan mahasiswa tersebut merasa mampu untuk mengerjakan dan menyelesaikan oleh diri sendiri atas permasalahan yang ada dalam usaha sehingga mempunyai minat berwirausaha.

Hasil penelitian ini sejalan dengan penelitian yang dilakukan olehAnies (2016), Grisna (2016), Yulianti (2016), dan Juhariyah (2018) menyatakan bahwa sikap mandiri berpengaruh positif dan signifikan terhadap minat berwirausaha. Namun, hal ini bertentangan dengan penelitian yang dilakukan oleh Hermawan dan Sirine (2017) yang 
menyatakan bahwa sikap mandiri tidak berpengaruh signifikan terhadap minat berwirausaha.

\section{Pengaruh Lingkungan Keluarga Terhadap Minat Berwirausaha}

Hasil pengujian hipotesis (H3) telah membuktikan bahwa variabel lingkungan keluarga berpengaruh positif dan signifikan terhadap minat berwirausaha pada mahasiswa perguruan tinggi di Purwokertodengan nilai $t$ hitung $>t$ tabel yaitu 5,953>1,657 dengan nilai signifikansi sebesar $0,000<0,05$, yang artinya lingkungan keluarga menjadi salah satu alasan mahasiswa berminat untuk berwirausaha karena keluarga menjadi motivasi mahasiswa untuk berwirausaha.

Hasil penelitian ini sejalan dengan penelitian yang dilakukan olehAnies (2016), Ni Putu (2016), Ri’Fatul (2015), Richard (2015), Samuel (2017), dan Mega (2017) menyatakan bahwa lingkungan keluarga berpengaruh positif dan signifikan terhadap minat berwirausaha. Namun, hal ini bertentangan dengan penelitian yang dilakukan oleh Syahid (2019) yang menyatakan bahwa lingkungan keluarga tidak berpengaruh positif dan signifikan terhadap minat berwirausaha.

\section{Pengaruh Motivasi Terhadap Minat Berwirausaha}

Hasil pengujian hipotesis (H4) telah membuktikan bahwa variabel motivasi berpengaruh positif dan signifikan terhadap minat berwirausaha pada mahasiswa perguruan tinggi di Purwokertodengan nilai t hitung $>\mathrm{t}$ tabel yaitu 2,115>1,657 dengan nilai signifikansi sebesar $0,036<0,05$, yang artinya mahasiswa merasa bahwa dirinya mampu untuk menciptakan nilai tambah dalam suatu produk karena memiliki minat dalam menjadi wirausahawan sehingga menjadi alasan untuk meningkatkan minat berwirausaha.

Hasil penelitian ini sejalan dengan penelitian yang dilakukan oleh Anies (2016), Syahid (2019), Roro (2019), Ni Luh (2019), Asep (2018), dan Yulianti (2019) menyatakan bahwa motivasi berpengaruh positif dan signifikan terhadap minat berwirausaha. Namun, hal ini bertentangan dengan penelitian yang dilakukan oleh Josia dan Hani (2017) yang menyatakan bahwa motivasi tidak berpengaruh positif dan signifikan terhadap minat berwirausaha.

\section{Pengaruh Pengetahuan Kewirausahaan Terhadap Minat Berwirausaha}

Hasil pengujian hipotesis (H5) telah membuktikan bahwa variabel pengetahuan kewirausahaan berpengaruh positif dan signifikan terhadap minat berwirausaha pada mahasiswa perguruan tinggi di Purwokertodengan nilai t hitung $>\mathrm{t}$ tabel yaitu 5,052> 1,657 dengan nilai signifikansi sebesar $0,000<0,05$, yang artinya mahasiswa berani mengambil resiko dan bisa menganalisis usaha karena memiliki pengetahuan kewirausahaan yang mana bisa meningkatkan minat berwirausaha.

Hasil penelitian ini sejalan dengan penelitian yang dilakukan oleh Josia dan Hani (2017), Ni Luh (2019), Ri'fatul (2015), Juhariyah (2018), dan Yulianti (2019) menyatakan bahwa pengetahuan kewirausahaan berpengaruh positif dan signifikan terhadap minat berwirausaha.

\section{PENUTUP}

Berdasarkan hasil penelitian sebanyak 130 responden dapat diambil kesimpulan sebagai berikut Sikap mandiri, lingkungan keluarga, motivasi, dan pengetahuan kewirausahaan berpengaruh secara parsial terhadap minat berwirausaha pada mahasiswa perguruan tinggi di Purwokerto.

Penelitian ini terdapat beberapa keterbatasan, diantaranya adalah sebagai berikut : 
Sampel yang digunakan dalam penelitian ini hanya 130 responden, sehingga tidak menutup kemungkinan akan adanya hasil yang berbeda jika sampel yang digunakan lebih banyak.

Berdasarkan hasil penelitian Adjusted $R$ Squaremodel regresi yang terbentuk dalam penelitian ini adalah sebesar 0,610 yang artinya sebesar 61,0\% variasi variabel Minat Berwirausaha dapat dijelaskan oleh variabel Sikap Mandiri, Lingkungan Keluarga, Motivasi dan Pengetahuan. Sedangkan sisanya sebesar 39,0\% dijelaskan oleh variabel lain yang tidak diteliti.Maka peneliti menyarankan kepada peneliti selanjutnya untuk menambah variabel yang memungkinkan berpengaruh terhadap minat berwirausaha, misalnya lingkungan teknologi, inovasi dan kreatifitas, efikasi diri, dan lain-lain.

\section{DAFTAR PUSTAKA}

Aini, M. P. N., Santosa, S., \& Hamidi, N. (2017). Pengaruh Lingkungan Keluarga Dan Lingkungan Sekolah Terhadap Minat Berwirausaha. Pendidikan Akuntansi, FKIP Universitas Sebelas Maret Surakarta, 57126, Indonesia, 3(2), 1-10.

Anggadwita, G., \& Dhewanto, W. (2016). The influence of personal attitude and socialperception on women entrepreneurial intentions in micro and small enterprises in Indonesia. International Journal of Entrepreneurship and Small Business, 27(2-3), 131-148.

Anggraeni, B., Harnanik. (2015). Pengaruh pengetahuan kewirausahaan dan lingkungan keluarga terhadap minat berwirausaha siswa kelas XI SMK ISLAM NUSANTARA COMAL kabupaten Pemalang. Jurnal Pendidikan Ekonomi Dinamika Pendidikan, 10(01), 42-52.

Ardiyani, N., \& Kusuma, A. (2016). Pengaruh Sikap, Pendidikan Dan Lingkungan Keluarga Terhadap Minat Berwirausaha. E-Jurnal Manajemen Universitas Udayana, 5(8), 254988.

Badan Pusat Statistik [Internet]. Tersedia dalam : bps.go.id

Denanyoh, R., Adjei, K., \& Nyemekye, G. E. (2015). Factors That Impact on Entrepreneurial Intention of Tertiary Students in Ghana. Factors That Impact on Entrepreneurial Intention of Tertiary Students in Ghana, 5(3), 19-29

Ghozali, Imam. 2018. Aplikasi Analisis Multivariate dengan Program IBM SPSS 25 edisi 9. Semarang:Badan Peneliti Universitas Diponogoro.

Hendrawan, J. S., \& Sirine, H. (2017). Pengaruh Sikap Mandiri, Motivasi, PengetahuanKewirausahaan Terhadap Minat Berwirausaha. Journal of Innovation and Entrepreneurship, 02(03), 291-314.

Hutagalung, B., \&Dalimunthe, J. D. M., Pambudi, R., Hutagalung, Q. A., Muda, I. (2017). The effect of Entrepreneurship, Education, and Family Environment Towards Students' Entrepreneur Motivation. International Journal of economics Research, E-ISSN:0972-9380, 14(20), 331-348.

Kementrian Perindustrian [Internet]. Tersedia dalam : Kemenperin.go.id (Accesed 3 maret 2021)

Lestari, Anisa., Hasiolan, A.B., Minarsih, M.M. (2016). Pengaruh Sikap Mandiri, Lingkungan Keluarga, Dan Motivasi Terhadap Minat Berwirausaha Para Remaja. Journal Of Management, 02(02), 1-14.

Maftuah, R. (2015). Pengaruh Efikasi Diri, Lingkungan Keluarga, dan Pengetahuan Kewirausahaan terhadap Minat Berwirausaha Siswa SMK di Sidoarjo. Jurnal Ekonomi Pendidikan Dan Kewirausahaan, 3(1), 121-131.

Muhammad, A.D., Aliyu, S., Ahmed, S. (2015). Entrepreneurial Intention Among Nigerian University Students. American Journal Of Business Education-

Fourth Quarter, 08(04), 239-248. 
Munawar, A., \& Supriatna, N. (2018). Pengaruh Sikap Dan Motivasi Terhadap Minat Berwirausaha Siswa. OIKOS Jurnal Kajian Pendidikan Ekonomi Dan Ilmu Ekonomi, II, 14-23.

Pangkalan Data Pendidikan Tinggi [Internet]. Tersedia dalam : pddikti.kemdikbud.go.id (Accesed 3 maret 2021)

Susanto, S. C. (2017). Pengaruh lingkungan keluarga, pendidikan kewirausahaan, dan efikasi diri terhadap minat berwirausaha mahasiswa. Jurnal Manajemen Dan Start-Up Bisnis, 2(3), 277-286.

Sugiyono, 2016.Metode Penelitian Manajemen Pendekatan Kuantitatif, Kualitatif, Kombinasi (Mixed Methods), Penelitian Tindakan (Action Research) dan Penelitian Evaluasi.Bandung : Penerbit Alfabeta.

Sujarweni, Wiratna V. 2015. Metode Penelitian Binis \& Ekonomi. Yogyakrata: Pustaka Baru Pers. 
